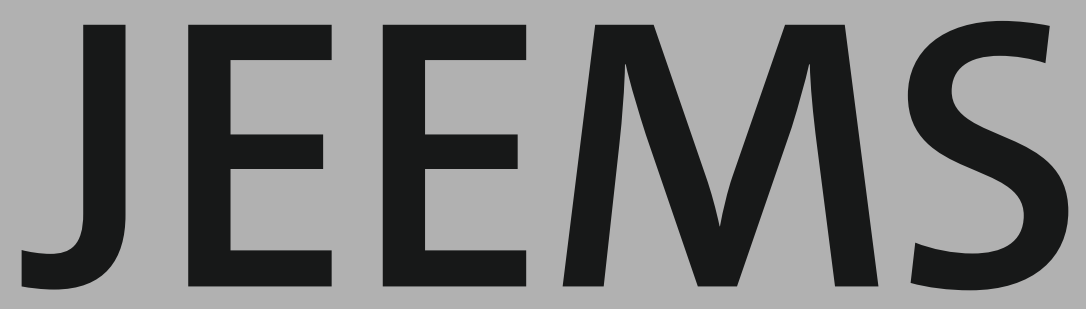

Journal of East European Management Studies

Archiv

Vol. 19, issue 3, 2014 


\section{Journal of East European Management Studies (JEEMS)}

Editorial Committee: Thomas Steger (Editor-in-chief), University of Regensburg

Rainhart Lang, Chemnitz University of Technology Irma Rybnikova, Chemnitz University of Technology

Advisory Board: Ed Clark, Royal Holloway University of London

Eckhard Dittrich, Otto-von-Guericke-University of Magdeburg

Miklós Dobák, Corvinus University of Budapest

Ivan Nový, University of Economics Prague

Anna Soulsby, Nottingham University Business School

Dieter Wagner, University of Potsdam

Honorary Board: Vince Edwards, Buckinghamshire College

Dirk Holtbrügge, University of Erlangen-Nürnberg

Fred Luthans, University of Nebraska Lincoln

Sheila M. Puffer, Northeastern University Boston

Rudi Schmidt, Friedrich-Schiller-University of Jena

Raoul Üksvärav, University of Tallinn

Hartmut Wächter, University of Trier $†$

Ingo Winkler, University of Southern Denmark

\section{Editorial Board:}

R. Alas, Estonian Business School

G. Bakacsi, Corvinus University of Budapest

K. Balaton, Corvinus University of Budapest

G. Belz, Wroclaw University of Economics

S. Blazejewski, Alanus University

D.J. Bourne, Queen Mary University of London

Z. Buzády, CEU Business School, Budapest

D. Catana, Technical University of Cluj-Napoca

T. Čater, University of Ljubljana

S.-O. Collin, Linnæus University

B. Dallago, Università di Trento

M. Dowling, University of Regensburg

J. Erpenbeck, SIBE Herrenberg

J.H. Fisch, University of Economics Vienna

A. Geigenmüller, Ilmenau University of Technology

M. Geppert, Friedrich-Schiller-University of Jena

V. Golikova, Higher School of Economics, Moscow

I. Gurkov, Higher School of Economics, Moscow

B. Heidrich, Budapest Business School

J. Hentze, Technical University of Braunschweig

N. Hermes, University of Groningen

N. Holden, University of Leeds
G. Hollinshead, University of Hertfordshire

A. Ishikawa, Chuo University

J. Kovac, University of Maribor

K. Liuhto, Turku School of Economics

S. Llaci, University of Tirana

R.-E. Lungwitz, Friedrich-Schiller-University of Jena

C. Makó, Hungarian Academy of Science Budapest

M. Malý, University of Economics Prague

W. Mayrhofer, University of Economics Vienna

S. Michailova, University of Auckland Business School

J.-P. Neveu, Université de Montpellier 2

R. Nurmi, Turku School of Economics

A. Pocztowski, Cracow University of Economics

E. Polyakov, Sulzer Pumps (UK) Ltd.

T. Postma, University of Groningen

D. Pučko, University of Ljubljana

A. Remisova, Comenius University Bratislava

T. Specker, University of Applied Sciences Kiel

C. Stojanov, Otto-von-Guericke-University of Magdeburg

E. Szabo, Johannes-Kepler-University Linz

P. Wald, University of Applied Sciences Leipzig

Address:

JEEMS, c/o Lehrstuhl Führung und Organisation, Universität Regensburg, Universitätsstr. 31, D- 93053 Regensburg Tel.: +49941943 2680, Fax: +499419434206

E-Mail: thomas.steger@wiwi.uni-regensburg.de URL: http://www.hampp-verlag.de/Hampp_JEEMS.html 


\section{Journal of East European Management Studies}

\section{Print: ISSN 0949-6181 Internet: 1862-0019}

The Journal of East European Management Journal (JEEMS) is published four times a year. The personal subscription rate is $€ 80,00$, the institutional rate (IP account + print) is $€ 150,00$ including delivery and value added tax. For delivery outside Germany an additional $€ 12,00$ are added. Cancellation is only possible six weeks before the end of each year. Single issues of JEEMS may be obtained at $€$ 24,80

The contributions published in JEEMS are protected by copyright. No part of this publication may be translated into other languages, reproduced, stored in a retrieval system or transmitted in any form or by any means, electronic, magnetic tape, photocopying, recording or otherwise without permission in writing from the publisher. That includes the use in lectures, radio, TV or other forms. Copies are only permitted for private purposes and use and only of single contributions or parts of them.

For any copy produced or used in a private corperation serving private purposes (due to §54(2) UrhG) one is obliged to pay a fee to VG Wort, Abteilung Wissenschaft Goethestraße 49, D-80336 München, where one can ask for details.

Das Journal of East European Management Studies (JEEMS) erscheint 4x im Jahr. Der jährliche Abonnementpreis für Privatpersonen (Printausgabe) beträgt 80,00 €, für Institutionen (IP-Zugang + Print) $€ 150,00$ inkl. MWSt und Versandkosten. Für den Versand ins Ausland werden jeweils zusätzlich 12,00 € berechnet. Kündigungsmöglichkeit: 6 Wochen vor Jahresende. Einzelhefte von JEEMS sind zum Preis von 24,80 € erhältlich.

Die in der Zeitschrift JEEMS veröffentlichten Beiträge sind urheberrechtlich geschützt. Alle Rechte, insbesondere das der Übersetzung in fremde Sprachen, vorbehalten. Kein Teil darf ohne schriftliche Genehmigung des Verlages in irgendeiner Form - durch Fotokopie, Mikrofilm oder andere Verfahren reproduziert oder in eine von Maschinen, insbesondere von Datenverarbeitungsanlagen, verwendete Sprache übertragen werden. Auch die Rechte der Weitergabe durch Vortrag, Funk- und Fernsehsendung, im Magnettonverfahren oder ähnlichem Wege bleiben vorbehalten. Fotokopien für den persönlichen und sonstigen eigenen Gebrauch dürfen nur von einzelnen Beiträgen oder Teilen daraus als Einzelkopien hergestellt werden.

Jede im Bereich eines gewerblichen Unternehmens hergestellte oder benützte Kopie dient gewerblichen Zwecken gemäß § 54(2) UrhG und verpflichtet zur Gebührenzahlung an die VG Wort, Abteilung Wissenschaft, Goethestraße 49, D-80336 München, von der die einzelnen Zahlungsmodalitäten zu erfragen sind.

Journal of East European Management Studies is being indexed by Social Sciences Citation of the Index ${ }^{\circledR}$ and by the International Bibliography of the Social Sciences (IBSS).

Database Research Pool: www.hampp-verlag.de

Six journals - one search engine: Our new online-archive allows for searching in full-text databases covering five journals:

- Industrielle Beziehungen, beginning in 1998

- International Journal of Action Research, beginning in 2005

- Journal of East European Management Studies, beginning in 1998

- management revue, beginning in 2004

- Zeitschrift für Personalforschung, beginning in 1998

- Zeitschrift für Wirtschafts- und Unternehmensethik, beginning in 1998

Free research: Research is free. You have free access to all hits for your search. The hit list shows the relevant articles relevant to your search. In addition, the list references the articles found in detail (journal, volume etc.).

Browse or download articles via GBI: If you want to have access to the full-text article, our onlinepartner GENIOS will raise a fee of 10.- Euro. If you are registered as a „GENIOS-Professional Customer" you may pay via credit card or invoice. 
JEEMS • Volume $19 \bullet$ Number $3 \cdot 2014$

Editorial

Rainhart Lang

Articles

Janez Prašnikar, Dragan Mikerević, Damjan Voje

Blockholding and organisational diversity: the case of a transition economy

Roger Moser, Christian Paul Jian Wei Kuklinski,

Markus Weidmann

The impact of institutions on the resources of foreign companies: the case of third party logistics service providers in Russia

Noémi Csigéné Nagypál

Corporate social responsibility of Hungarian SMEs

with good environmental practices

Biljana Ratković Njegovan, Iva Šiđanin

Public broadcasting crisis as management crisis: a case study of radio television of Vojvodina

News/Information 


\section{Editorial Mission of JEEMS}

The main aim of the Journal of East European Management Studies (JEEMS) is to promote dialogue and cooperation among scholars from all countries who seek to examine, explore and explain the behaviour and practices of management within the transforming societies of Central and Eastern Europe. As such, the theoretical interests of the journal focus on a) organizational and management change; b) Central and East European societies (including those on the fringes of Europe) undergoing processes of transition or transformation; and c) scientific issues of business, management and organisation that arise in such contexts. In this regard, JEEMS particularly welcomes papers that draw on a behavioral perspective.

By fostering the exchange of ideas within the academic community and between management academics and management practitioners, JEEMS aims to contribute to the development of knowledge and practice across the Central and East European region. In this way, the journal hopes to cultivate and spread a sophisticated understanding of management trends and tendencies as they emerge through the process of transformation. The concern with management practices and issues is meant in the broadest sense to include the problems of steering politico-economic processes and the management of all types of organized action and their social embeddedness.

JEEMS aims to attract social scientific contributions from scholars of any nation and region, but particularly wishes to encourage authors from those countries directly experiencing transformational change. Its potential readership is international, comprising academics and practitioners with an involvement or interest in the management of change in transforming societies in Central and Eastern Europe. 